K/GD-1631, Rev. 1

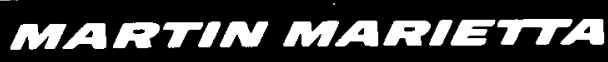

$\hat{i}$

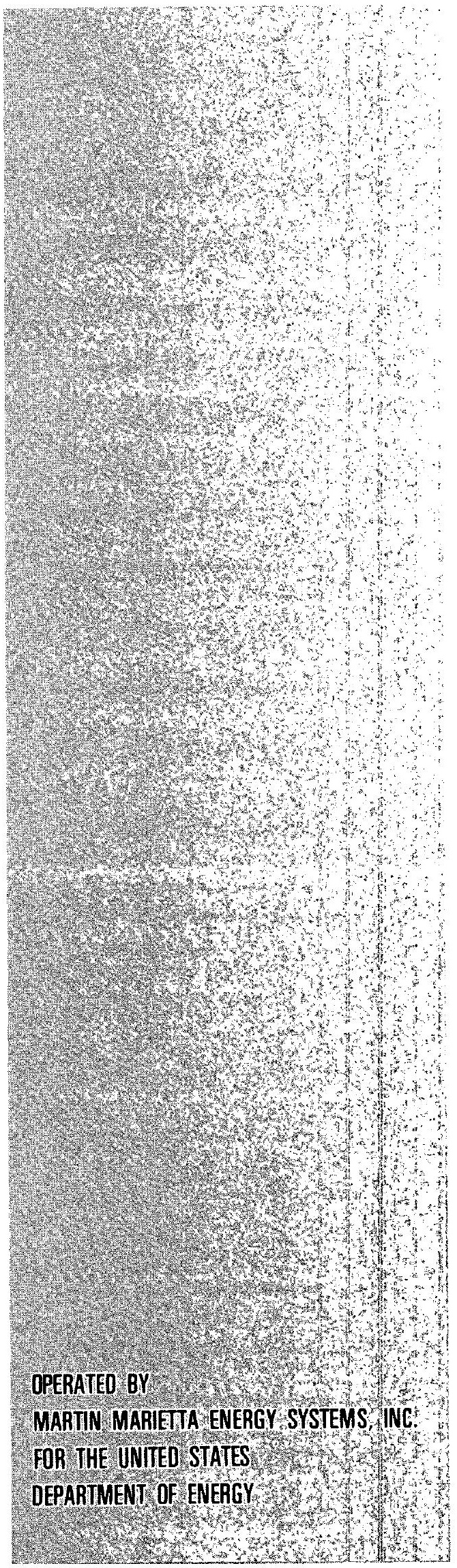

Rocurad on ort

MAR 201986

THE PATTERN OF EXPLOSIVE REACTION BETWEEN URANIUM HEXAFLUORIDE AND HYDROCARBON OILS

Kar1 E. Rapp

Oak Ridge Gaseous Diffusion Plant

March 21, 1986 


\section{DISCLAIMER}

This report was prepared as an account of work sponsored by an agency of the United States Government. Neither the United States Government nor any agency thereof, nor any of their employees, make any warranty, express or implied, or assumes any legal liability or responsibility for the accuracy, completeness, or usefulness of any information, apparatus, product, or process disclosed, or represents that its use would not infringe privately owned rights. Reference herein to any specific commercial product, process, or service by trade name, trademark, manufacturer, or otherwise does not necessarily constitute or imply its endorsement, recommendation, or favoring by the United States Government or any agency thereof. The views and opinions of authors expressed herein do not necessarily state or reflect those of the United States Government or any agency thereof. 


\section{DISCLAIMER}

Portions of this document may be illegible in electronic image products. Images are produced from the best available original document. 
The Pattern of Explosive Reaction Between

Uranium Hexafluoride and Hydrocarbon Oils

Karl E. Rapp

[Keywords: Explosive Reactions, Uranium Hexafluoride--Impurities-Reactions--Releases--Temperature Ef fects; Hydrocarbons ]

Examination of uranium hexafluoride release incidents occurring over the past three decades of ORGDP experience has identified only four which apparently involved an explosion of a container resulting from reaction between uranium hexafluoride and an impurity. These four incidents exhibit a certain degree of commonality. Each has involved (a) condensed phase uranium hexafluoride, (b) a moderately elevated temperature, (c) a sufficient quantity of uranium hexafluoride for a significant partial pressure to be maintained independently above that which can be consumed by chemical reaction, and (d) an organic liquid (probably hydrocarbon oil) accidentally present in the container as a contaminant.

The purpose of this investigative search was to establish some conditional pattern for these four incidents to which their violent consequences could be attributed. Fortunately, the number of such incidents is relatively small, which emphasizes even more pointedly the unfortunate fact that documentation ranges from thorough to very limited. Documented sources of information are given in the bibliography. Copies of those which are not readily available are contained in six appendices. Descriptively, the incidents are identified chronologically as follows:

1949

This incident of March 7 involved explosion of a laboratory cold trap in which a quantity of $\mathrm{UF}_{6}$ apparently had been collected. The explosion took place as the trap was being heated preparatory to vapor transferring its accountable contents to a larger trap for condensed UF 6 . Material recovered after the release consisted of a black carbonaceous smoke which settled rapidly to give maximum surface readings of $20,000 \mathrm{cpm}^{1}$

1953

On May 25, personnel were using a hot water bath in $\mathrm{K}-413$ to heat a cold trapping cylinder (300-1b capacity) containing 123 lb of UF6 preparatory to making a vapor transfer of the contents to a larger cylinder. Shortly after the cylinder was placed in the hot water it ruptured explosively. ${ }^{2}$ Analysis revealed carbon and reduced uranium in the residue found at the explosion scene. ${ }^{3}$

1955

On March 10, a type 12A feed cylinder of $\mathrm{UF}_{6}$ exploded as it was being heated in the vaporization room of $\mathrm{K}-33$ allowing over $5001 \mathrm{~b}$ of $\mathrm{UF}_{6}$ to be released from this and another cylinder. About $100 \mathrm{lb}$ of the released 
material was recovered. Analyses of samples of various residues found in the room afterward showed part of the uranium in the reduced state and an elevated carbon content. ${ }^{4}, 5$

1975

On September 17, shortly after being filled with liquid UF 6 at $\mathrm{K}-1423$, a $30 \mathrm{~A}$ cylinder (Nukem-8) suffered detonation which caused both concave ends of the cylinder to bulge. Cracks were developed in both the valve body and the cylinder wall at the opposite end resulting in the release of $18 \mathrm{lb}$ of $\mathrm{UF}_{6}$. Solid residues found in the cylinder after the unreacted $\mathrm{UF}_{6}$ had been fed to the gaseous diffusion cascade consisted of $\beta$ UF $_{5}$ containing about $4 \% \mathrm{U}_{2} \mathrm{~F}_{9}$ in association with a small amount of fluorinated carbonaceous material. ${ }^{6}$ About $2001 \mathrm{~b}$ of $U$ were recovered from the residues.

Although the four elements of commonality are not so readily apparent, one would be remiss should he fail to consider a fifth explosive release incident which predated these four. On May 8, 1947 at K-131 during a transfer of liquid $\mathrm{UF}_{6}$ from a $12 \mathrm{~A}$ cylinder to one with a capacity of $4500 \mathrm{lb}$, a piece of heated, flexible metal hose being used for pressure equalization exploded while supposedly in contact with only the vapor phase in a heated cylinder filled with liquid $\mathrm{UF}_{6}$. Several pounds of $\mathrm{UF}_{6}$ was released before the cylinder valves could be closed. The investigation which followed the incident revealed evidence that the flexible hose was contaminated with hydrocarbon oil. The presence of a copious residue of reduced uranium fluoride indicated liquid $\mathrm{UF}_{6} 6$ may have been involved in the explosive oxidation-reduction reaction ${ }^{7}$.

Experimental and Related Incidents

That a significant quantity of an organic contaminant was present and contributed to the explosion is indicated in each of these incidents by the carbonaceous residues. Because its introduction was unintentional, its presence remained unsuspected until the explosion. In the last and most completely documented incident a test was conducted to simulate the Kinney pump failure which occurred during evacuation of the $30 \mathrm{~A}$ cylinder after a new valve was installed. This test dramatically demonstrated that over $1300 \mathrm{~g}$ of hydrocarbon oil could have backed up into the cylinder from the failed pump. ${ }^{6}$ Although no such demonstration was conducted to simulate conditions which prevailed before any of the other explosion incidents, the very fact that a hydrocarbon oil pump had been used preparatory to filling each of the containers provided a necessary opportunity for organic contamination of the container.

Several experimental reactions with $\mathrm{UF}_{6}$ and hydrocarbon oils were conducted relative to two of these incidents. A separate non-explosive release incident was brought to light during this survey and is discussed here because of the insight it provides to the fundamental reaction between $\mathrm{UF}_{6}$ and hydrocarbon oil. 


$$
\begin{array}{r}
\text { K/GD-1631, Rev. } 1 \\
\text { Page } 4
\end{array}
$$

The experiments performed by A. V. Faloon and the author to which Rhees alludes in his analysis of the residues from the 1953 incident $^{3}$ indicated that "reaction between uranium hexafluoride and hydrocarbon oil becomes vigorous at $70-90^{\circ} \mathrm{C}$, forming $\mathrm{UF}_{4}$, carbon, and low molecular weight fluorinated compounds $\left(\mathrm{CF}_{4}, \mathrm{C}_{2} \mathrm{~F}_{6}, \mathrm{C}_{3} \mathrm{~F}_{8}, \mathrm{C}_{4} \mathrm{~F}_{10}\right) . "$ These experiments were carried out in a high pressure reactor with liquid hydrocarbon oil and initially condensed (solid) $\mathrm{UF}_{6}$. The temperature and pressure were observed remotely behind a barricade while heat was applied to the reactor at a constant rate. When an increase in the reaction rate became obvious from the accelerated rates of temperature and pressure rise, the reactor heater was turned off, and water cooling was applied. A mass spectrometer scan of the gaseous products of the reaction indicated complete fluorination of the fragmented hydrocarbon chain. The residue in the reactor consisted of $\mathrm{UF}_{4}$ and carbon. Had the $\mathrm{UF}_{6}$ been present in sufficient supply, the reaction could probably have been represented by the following simplified equation:

$$
\begin{aligned}
& \mathrm{H}-\left(\mathrm{CH}_{2}\right)_{\mathrm{n}}-\mathrm{H}+[2(\mathrm{n}+1)+\mathrm{x}] \mathrm{UF}_{6} \rightarrow[2(\mathrm{n}+1)+\mathrm{x}] \mathrm{UF}_{4} \\
& +\mathrm{F}-\left(\mathrm{CF}_{2}\right)_{\mathrm{m}}-\mathrm{F}+2(\mathrm{n}+1) \mathrm{HF}
\end{aligned}
$$

where $x$ represents the number of $\mathrm{C}-\mathrm{C}$ bonds broken and fluorinated during the reaction to produce the mixture of low molecular weight fluorocarbons represented by $F-\left(C_{2}\right)_{m}-F$. Where excess $U_{6}$ is involved the reduced uranium most probably would consist of some $\mathrm{UF}_{5}, \mathrm{U}_{2} \mathrm{~F}_{9}$ and/or $\mathrm{U}_{4} \mathrm{~F}_{17}$ in amounts stoichiometrically equivalent to the UF 4 shown.

On December 29, 1974 a K-33 electrical transformer and substation failure occurred. In connection with the subsequent investigation of the incident a sluggishly operating seal exhaust pump was discovered. ${ }^{8}$ Although the pump was not responsible for the electrical fault, the related analytical findings seem to confirm the smooth reaction projected above. A comparatively high seal leak rate apparently escaped detection until the traps protecting the hydrocarbon oil pumps became saturated with $\mathrm{UF}_{6}$. The gas then passed unchecked into the oil. There it was intimately mixed by the pump action and reacted smoothly at the normally elevated operating temperature of the pump. Continued unobserved reaction was favored by the constant removal of gaseous reaction products via the pump exhaust to the roof.

By way of contrast, negligible reaction was observed in the two laboratory studies described in the analytical results section of the 1975 release incident report. ${ }^{6}$ In these experiments $\mathrm{UF}_{6}$ vapor at a maximum pressure of 500 torr in contact with the surface of hydrocarbon oil at $200^{\circ} \mathrm{F}$ was insufficient to initiate a sustained reaction even though the oil was thinly distributed to expose a relatively high surface area to the gas.

\section{Conclusions and Recommendations}

In each of the four explosive release incidents the handling of $\mathrm{UF}_{6}$ as a condensed phase was intentional and in three of them the application was 
a necessary part of the operation being performed. The container involved in the fourth incident would normally have been heated at a later date had detonation not occurred when it did. In this sense the fourth explosive release fortunately took place prematurely, where the facilities and skill to dispose of the unreacted $\mathrm{UF}_{6}$ safely were more readily available than might have been the case later. The only condition prevailing in all these incidents which was neither intentional nor a necessary part of the operation was the introduction of hydrocarbon oil. It is significant that recognition of the explosion potential demonstrated in three or four incidents occurring over an 8-year period resulted in the development of precautionary measures which proved effective for the next 20 years. Obviously the scrupulous exclusion of such contamination in the future offers the most reliable way of avoiding a recurrence of these hazardous and potentially costly incidents. In addition to the normal care exercised to maintain condensed $\mathrm{UF}_{6}$ containers free of contamination, it is recommended that the following precautions be taken irrespective of the scale of the operation:

(A) A hydrocarbon oil pump used to evacuate a container prior to the admission of $\mathrm{UF}_{6}$ should be connected to the container through a cold trap of sufficient volume that the entire hydrocarbon oil inventory of the pump can be contained. A cold trap is specified because it will prevent back diffusion of oil vapor to the container. An uncooled trap may suffice when only a rapid pump down operation is involved.

(B) In any transfer system subject to a possible transfer of $\mathrm{UF}_{6}$ vapor which can be condensed in the evacuation equipment, a means of evacuation should be employed which avoids use of hydrocarbon oil or other reactant fluid, e.g., an air ejector or a Krytox filled mechanical vacuum pump.

(C) Whenever and wherever the possibility exists that condensed $\mathrm{UF}_{6}$ may have inadvertently become contaminated with a reactive material such as hydrocarbon oil, a vapor phase transfer of the UF6 should be made at room temperature from the potentially contaminated container.

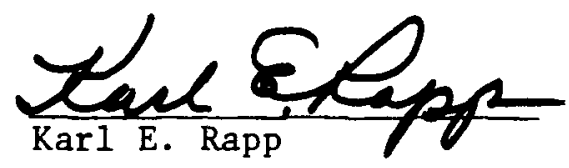




\section{Bibliography}

1. LaGraff, J., Foreman's Accident Report, Explosion and Material Release, K-1004A, Room 19, March 7, 1949, Carbide and Carbon Chemicals Corporation, Oak Ridge, Tennessee, March 11, 1949. (Official Use Only) (Appendix A).

2. Dyer, R. H., Arendt, J. W., Sabin, A. S., and Henry, H. F., Report of Property Domage Incident No. 11, Carbide and Carbon Chemicals Company, Oak Ridge, Tennessee, June 9, 1953, (KS-379). (Officlal Use Only) (Appendix B).

3. Rhees, R. C., Analysis of Residue from Cylinder Explosion in $K-413$, Carbide and Carbon Chemicals Company, Oak Ridge, Tennessee, June 9, 1953 (KLI-2310) (Official Use Only) (Appendix C).

4. Henry, H. F., Investigating Committee Report of an Explosion at $K-25$, Carbide and Carbon Chemicals Company, Oak Ridge, Tennessee, March 18, 1955 (KS-478) (Unclassified) (Appendix D).

5. Mottern, J. T., and Kwasnoski, T., Analysis of Residue from Cylinder Explosion in K-33, Carbide and Carbon Chemicals Company, Oak Ridge, Tennessee, April 6, 1955 (KLI-3451) (Official Use Only) (Appendix E).

6. Legeay, A. J., Ch., Investigation of a Uraniwn Hexafluoride Release Incident on September 17, 1975 in the K-1423 Toll Enrichment Facility, Union Carbide Corporation, Nuclear Division, Oak Ridge Gaseous Diffusion Plant, Oak Ridge, Tennessee, December 9, 1975 (K-P-6197) (Official Use Only).

7. Huber, A. P., Report of Explosion in Flexible Metal Hose During Transfer of Liquid C-616 in Fresh Feed Room, K-131, Thursday, May 8, 1947 at 12:45 P.M., Carbide and Carbon Chemicals Corporation, Oak Ridge, Tennessee, May 21, 1947 (Unclassified) (Appendix F).

8. Monk, T. H., Ch., Transformer and Substation Failure, December 29, 1947, Union Carbide Corporation, Nuclear Division, Oak Ridge Gaseous Diffusion Plant, Oak Ridge, Tennessee, April 21, 1974 (K-P-6146) (Unclassified). 
Distribution of K/GD-1631, dtd $3 / 3 / 77$

Oak Ridge Gaseous Diffusion Plant
L. W. Anderson
J. W. Arend $t$
B. I. V. Bailey
J. C. Bailey
E. J. Barber
O. L. Calvert
P. S. Cates
H. J. Culbert
L. A. Dean
J. O. Dodson
J. Dykstra
I. C. Flanders
J. F. Jamison
A. J. Legeay
R. W. Levin
W. D. McCluen
J. O. McCullough
M. E. Mitchell

Goodyear Atomic Corporation

J. G. Crawford

R. I. Kaplan

J. S. Murrell

N. F. Reiter

P. F. Seufzer

C. D. Tabor
R. B. Neal

R. L. Newton

J. H. Pashley

C. H. Peterson

K. E. Rapp

W. L. Richardson

J. E. Shoemaker

L. A. Smith

S. S. Stief

H. E. Trammell

R. J. Wertz

H. D. Whitehead, Jr.

W. J. Wilcox, Jr.

L. C. Willson

R. A. Winkel

K. T. Ziehlke

Library

Plant Records

Y-12 P1ant

J. M. Googin

R. G. Jordan

W. T. Mee

C. J. Parks

P. R. Vanstrum

Paducah Gaseous Diffusion Plant
H. D. Bewley
R. B. Gross
C. C. Hopkins
G. T. Hull
F. E. Kosinski 


\section{K/GD-1631, $\underset{\text { Page }}{\text { Rev. }} 1$}

Appendix A 

CARBIDE AND CARBON CHEMICALS CORP. L

FOREMAN'S ACCIDENT REPORT

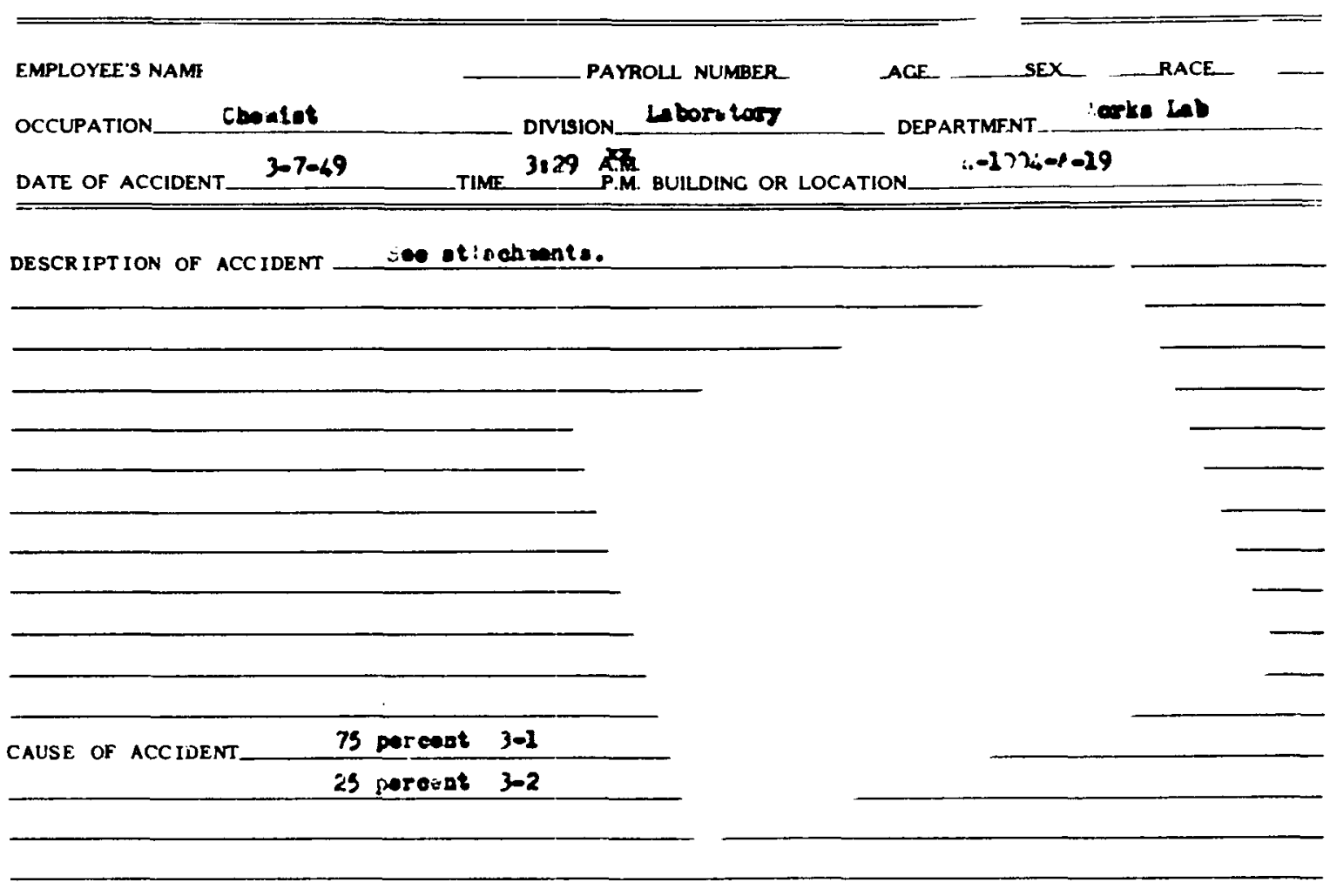

TYPE OF INJURY Lxpolure to $\mathrm{OF}_{6}$, arkniu beerla

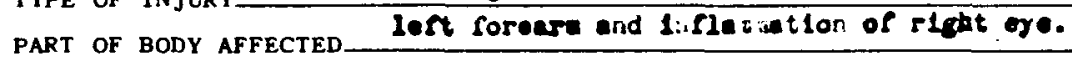

$$
\text { Date_ } \quad 3-12-49
$$

This Report to be submitted for all Accidents regardlens of extent of Injury and for all Occupational Diceases. 
POREIUN'S ACCIDENT REPORT

GXPLOSION AND AATBRILL RELEASE

X-1004-1 Roon 19 iarch 7, 1949

\section{Mivosiption of Accident}

had been canpling on the aystea shom in Pigure 1. During the saapling the ayoton hed boen evecuting oluggiohly. Thinking that trap 2 we getting rull of 016 , be closed velve 9, resoved the drylce-trichlorethylene elwh, and started waraing the trap wth a pyrofax-oxygen torch to transfer the UT6 to trap 1. He had atarted waraing tho trap at tho tog and was about halfiay to the botton won It exploded wtb a Iash and a loud noise.

wo standing ebout two foet fron the explosion and was covered from his wat up with a soots anterial. He incurred slight thermal burns on the right foreare and hle face and appeared to have som particles imbedded in b1: akin. His eyes were protected rrom the full force of the blast by safety glases, but sose dirt did go around the glasses and caused a alight inflammation of his right oge.

The tube part of tho trap blov 10080 roo the top and was driven dommard Wtb conelderab2o force. It appeared to heve stretched in diameter and then to have buckled os It struck a four logged stand that had been used to support the devar of cooling wodiun. It was found agalngt the wall as sbom in FIg. 2 .

The logs of the dewar stand were buckled. One leg which wes resting on - piece of half inch thick plyood was drived completels through the plywood, cutting out a plug.

$\Delta$ heary black dust aettled rapldy over two thirds of the room with maximus surface readings of 20,000 c.p.u. The naterial being sampled was approxieately normal. The dust wa readily cleanod up with demp nops and sponges. Surfaces showed no count after cleaning.

Threo other people were in the roos at the tine as shom on IIgure 20 None of these surfered any injury. One had to pase through the dust and smoke as be made hls way to the rront door and may have beon exposed.

left irmodiately through the front noor and pero not exposed.

An electrician,

was in the attic of the bullding and said be passed through somo swoke as be ade hia way to the trap door erit. snother electrician, - was in the elevetor pit in the basenent.

Tho ovecustion elarm wes sounded within ten seconds after the explosion at 3:29 P.A. danned an assault mask imediately, covered the floor vante that exhaust air into the beserent and opened some windows.

Air samples were taken in tho basenont, room 70 , and in roon 19 bo."ore anone reentered whout a mak. These samples taken 30-40 ninutes after tho explosion showed the alr contamination to bo below tolerance. 
K/GD-1631, Rev. 1

Page 11

Page 2

Causes:

1. The black sooty dust thet covered the room after the explosion Indicates thet an 1mconplete conbustion of puap oll occurred. Pump ofl could have diffused into the trap wile tho pump was running or could beve been sucked into the trap after the punp was atopped if soseone had falled to break the recuus op opening valve 10 in Figure 1.

2. The reaction probebly took place betwen the punp oil and fluorine or sove conpound of Iluorine. Tho nateriel boling sampled was UT6 aenufactured at $\mathrm{X}-1301$. It io known that this material contains fluorine, if and poselbly chrontue oxyfluorido. I sample teken from one of the cylladers previous to the explosion was about 50\% I1quid at roon temperature. In vapor sampling such waterial these voletile compounds are present in relatively large amounts in the firat gas that comes off.

3. Heating the trap probably atarted the reaction. However, the temperature at whioh such a reaction would start is not known although it 1s mom that bydrocarbons and fluorine may react violontly at liquid nitrogen temperature.

Remedies:

The following precautione are under conslderation:

1. Find some fool-proof way to prevent oll from getting into the trap.

2. Dse a Iluorlasted o11.

3. Install shielding around equipenat.

4. Purify fluoribated aterial before sampling.

5. Liquid sample these cylinders. 


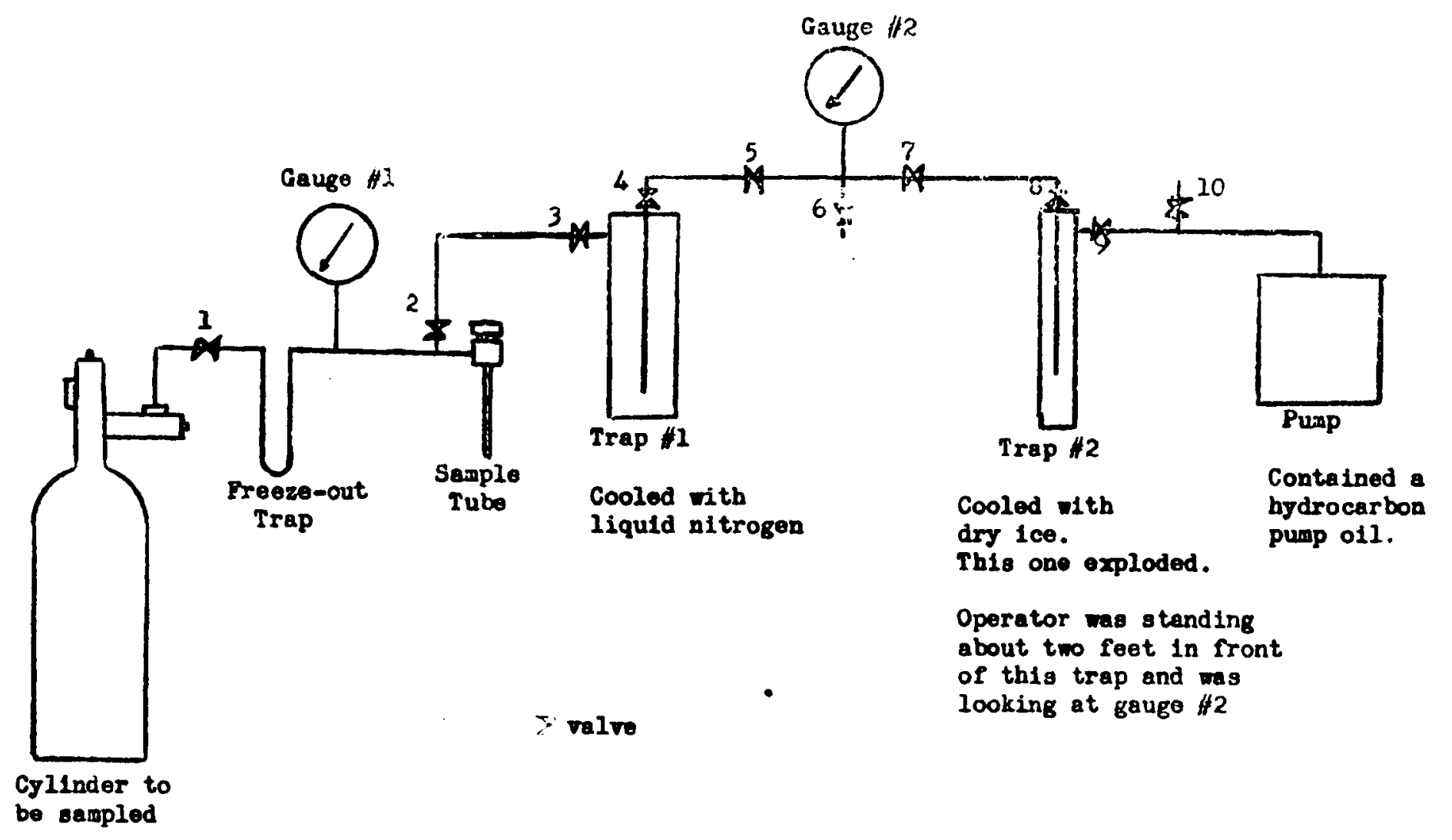

DIAGRAd OP SAMPLIMG SYSTE. ON KHICH EXPLOSION OCCUIRED 


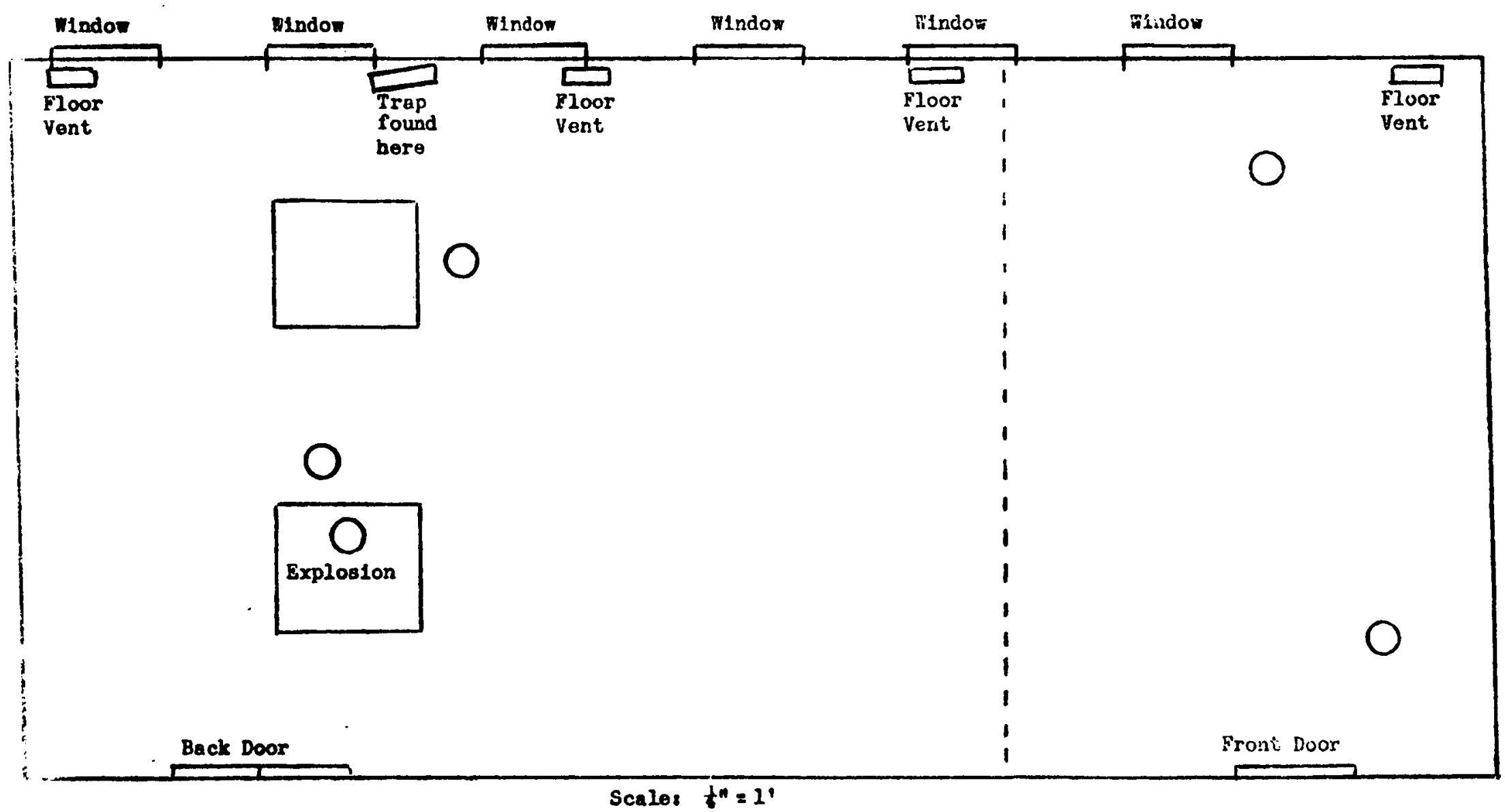

DIAGRAil OF ROOM 19, K-1004-A SHOIING LOCATION OF PEHSOMREL AT TI:E OF EXPLOSION All surfaces to left of dotted line were contaminated 
K/GD-1631, Rev. 1

Page 14

Appendix B 
INESTIGATING COMATTEE REPORT

OF EXPLOSION AT $\mathrm{K}-25$

$F R D-2$

RS-379

Description of Damaged Property: One cold-trap type cylinder, capacity

300 lb. UF 6 at $300 \%$ F, completely destroyed.

End of water bath, $3 \mathrm{ft} . x<\mathrm{ft} . x 5 \mathrm{ft}$, knocked off.

One wooden door knocked off its hinges.

Glass in one door removed and door itself damaged.

One set of chemical balances demolished.

Damage to miscellaneous measuring instrument 8 .

Step knocked out of expanded steel stairs and other damage do ne to stairs.

Hole broken in cyclone fencing.

Five window frames demolished.

Miscellaneous damage done to piping and interior walls of building.

Amount of Material Released: $\quad 123$ 1b. of normal UF6.

Extent of Damage to Government Property: Estimated $\$ 2,650$.

Time of Incident: 11:45 a.m., May 25, 1953.

Location of Incident: Building $\mathrm{K}-413$, Carbide and Carbon Chemicals Company, K-25 Plant, Oak Ridge, Tennessee.

Description of Incident: A cylinder, presumably containing only UF, was placed in a hot water bath for the purpose of transferring its contents to a larger container. A few moments later, as 2 employees were connecting it to the system, they noted that the cylinder wall was expanding and ran from the building. As they reached the door, a violent explosion occurred which ruptured the cylinder, blew out the building windows, and wrecked items of equipment in the room. Other than a ruptured eardrum sustained by 1 of the employees, injuries were confined to cuts and bruises but it was necessary to remove small imbedded particles from both men. A third employee working outside the building received a cut on his head from flying debris. 


\section{Findings :}

1. The contents of several small cylinders wich had been in storage since having been obtained from various locations throughout the plant over an extended period of time, were being combined in 1 large cylinder. The transfer was accomplished in the normal manner of vaporizing the UF 6 by heating the small cylinder, passing the $\mathrm{UF}_{6}$ through $a$ condenser, and then freezing it out again in the larger unit.

2. Ten cylinders of the same type as the cne which exploded had previously been emptied in this manner.

3. According to the statements of the employees concerned as well as other evidence, the events leading up to the accident were as follows:

a. This cylinder was the second of 2 such cylinders placed in the hot water bath.

b. The first cylinder had not been connected to the transfer manifold, it being normal practice to place both cylinders in the bath before connecting either one.

c. The employees were connecting the second cylinder to the manifold when they heard a small internal explosion and noted that the cylinder had expanded sufficiently to rise to the surface of the water.

d. The 2 employees had reached the door and turned to observe the cylinder when the principal explosion occurred. Although they were knocked to the ground, they escaped from the building unaided.

4. A third employee was working about $30 \mathrm{ft}$. from the outside wall of the building. He heard the explosion and simultaneously was hit by flying debris.

5. The violence of the explosion is attested by the attached photographs which are identified as follows:

a. Photograph No. 1. Outside of the building. The third employee was working at a point beyond the lower left edge of the photograph.

b. Photograph No. 2. Broken windows in the interior of the building, taken from the overhead pipe gallery.

c. Photographs Nos. 3 and 4. General views of room.

d. Photograph No. 5. Damage done to stairway by piece of metal. Metal had broken a hole in a length of cyclone fencing before striking these stairs which were about $30 \mathrm{ft}$. from the heating bath.

e. Photograph No. 6. Largest piece of cylinder found; it had Tooped itself in the insulated piping as shown.

f. Photograph No. 7. Damage done to transfer piping. The feed bath is also shown; the cylinder which did not explode was immediately frozen down with dry ice. 
6. The water in the feed bath was at a temperature of about $200^{\circ} \mathrm{F}$.

7. The history of the cylinder in the plant is as follows:

a. Prior to 1951 , it was used for miscellaneous $\mathrm{UF}_{6}$ trapping in the cascade.

b. In September, 1951, the cylinder was decontaminated and a revi sed valve arrangement was welded to it.

c. On October 1, 1951, it received a hydrostatic test at 400 psig. and an alr test at 100 psig.

d. After being stored, it was sent to the Barrier Pilot Plant in $\mathrm{K}-1401$ on June 11, 1952, and was installed in a freeze-out system there on July 17, 1952.

e. In service, the cylinder was normally kept at a temperature of about $-30^{\circ} \mathrm{F}$. in a mechanically refrigerated system. At one time during its use, the mechanical refrigeration system failed, but the cylinder had been valved from the remainder of the system at the time and the system temperature had been reduced with dry ice.

f. A Beach-Russ pump using hydrocarbon oil was a part of the freeze-out system; however, a cold trap was installed between the pump and this particular cylinder.

g. Part of the time that this cylinder was in service, it was used as a part of a system separating freon-114 and $\mathrm{UF}_{6}$.

$h$. On August 29, 1952, the cylinder was removed from the system and returned to storage with approximately 125 lb. of $\mathrm{UF}_{6}$ reported as being contained therein.

1. On April 28, 1953, this cylinder was one of more than a score sent to the $\mathrm{K}-4 \mathrm{I} 3$ Building for transfer of their contents to a large cylinder. This transfer procedure was also used as a part of experiments to determine the heating and cooling cycle of $\mathrm{UF}_{6}$ in these particular containers.

j. The transfer started on May 21 , and 10 cylinders had been emptied before this unit was placed in the system.

8. The cylinder, made of $1 / 4-i n$. monel, had a rated capacity of $300 \mathrm{lb}$. of $\mathrm{UF}_{6}$ at $3000 \mathrm{~F}$.

9. Calculations indicate that a pressure of approximately 1,250 psig. inside the cylinder would be necessary to produce the rupture observed.

10. Analysis of the material spread throughout the building indicated that most of the uranium found was in the tetravalent state, this indicating strong reduction of the originally hexavalent uranium. In addition, significant amounts of carbon and iron were found.

11. Although the interior of the building was heavily contaminated, no significant problem from contamination was noted outside.

\section{Conclusions:}

The committee could reach no definite conclusion of the cause of the explosion other than that it resulted from the reaction of $\mathrm{UF}_{6}$ and some unknown substance. It is suspected that this substance was hydrocarbon 
oil which had gotten into the cylinder in some way.

Recommendations:

Although it is obvlously difficult to establish procedures for preventing similar incidents when the cause of the accident in question is unknow and no significant operating faults are apparent, the implementation of the following recommendations of the investigating committee appears to encompass the major practicabie actions which the plant should take in attempting to prevent similar occurrences in the fluture:

1. In identifying the contents of UF cylinders sent to storage, employees should list possible contaminants.

2. Permanent barricaded facilities should be established for transfer or sampling operations and their use should be specified for those cases where the possibility of a dargerous reaction is suspected or the employees concerned are unfamiliar with the pioperties of the materials being handled.

3. Locations where miscellaneous sampling throughout the plant is done should be reduced and sampling operations thus be more centralized.

4. A thorough investigation, both of the literature and by experiment if necessary, should be made of the potential explosion hazards of mixtures of materials available at $\mathrm{K}-25$.

5. All systems used to fill cylinders with IF $_{6}$ should use fluorocarbon oil in their vacuum pumps rather than hydrocarbon oil.

H. F. Henry:lja

June 9, 1953
INVESTIGATING COMMITTEE

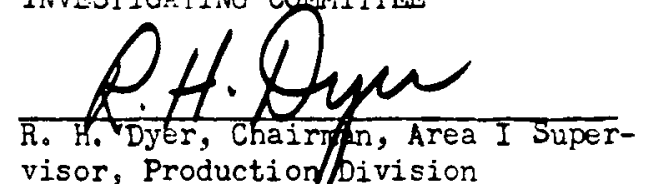

visor, Production bivision

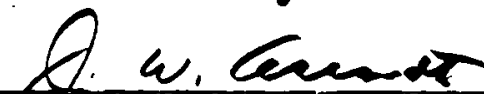

J. Wh Arendt, Member, SF-Materials

Optrol Supervisor, Production Division

E.c Mohinzen

for A. S. Satin, Member, Associate De-

velopment Engineer, Laboratory Division

thon 7 Renny

H. F. Uienry, Member, Safety and

Radiation Hazards Departmont Head, Safety and Protection Diysion 







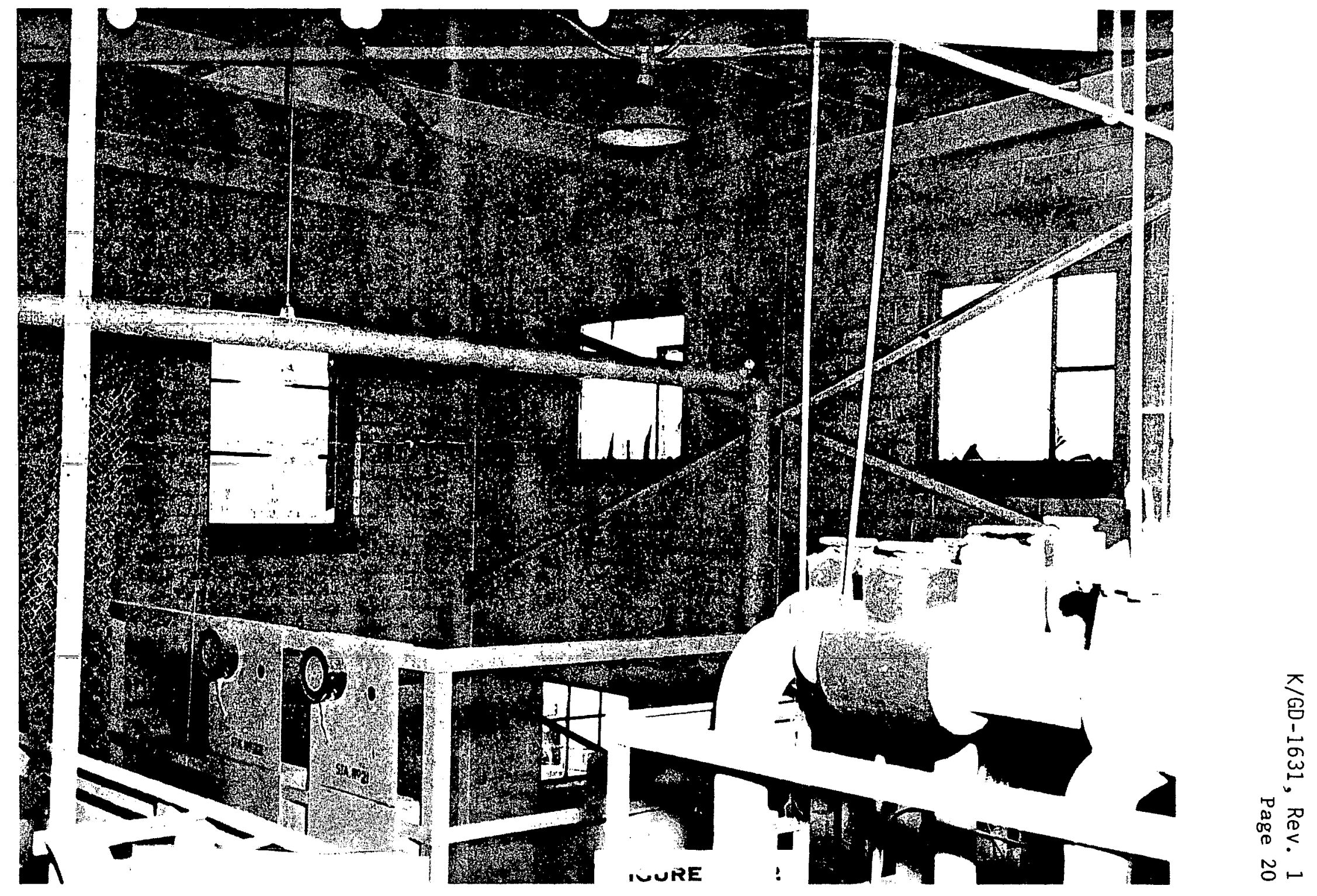




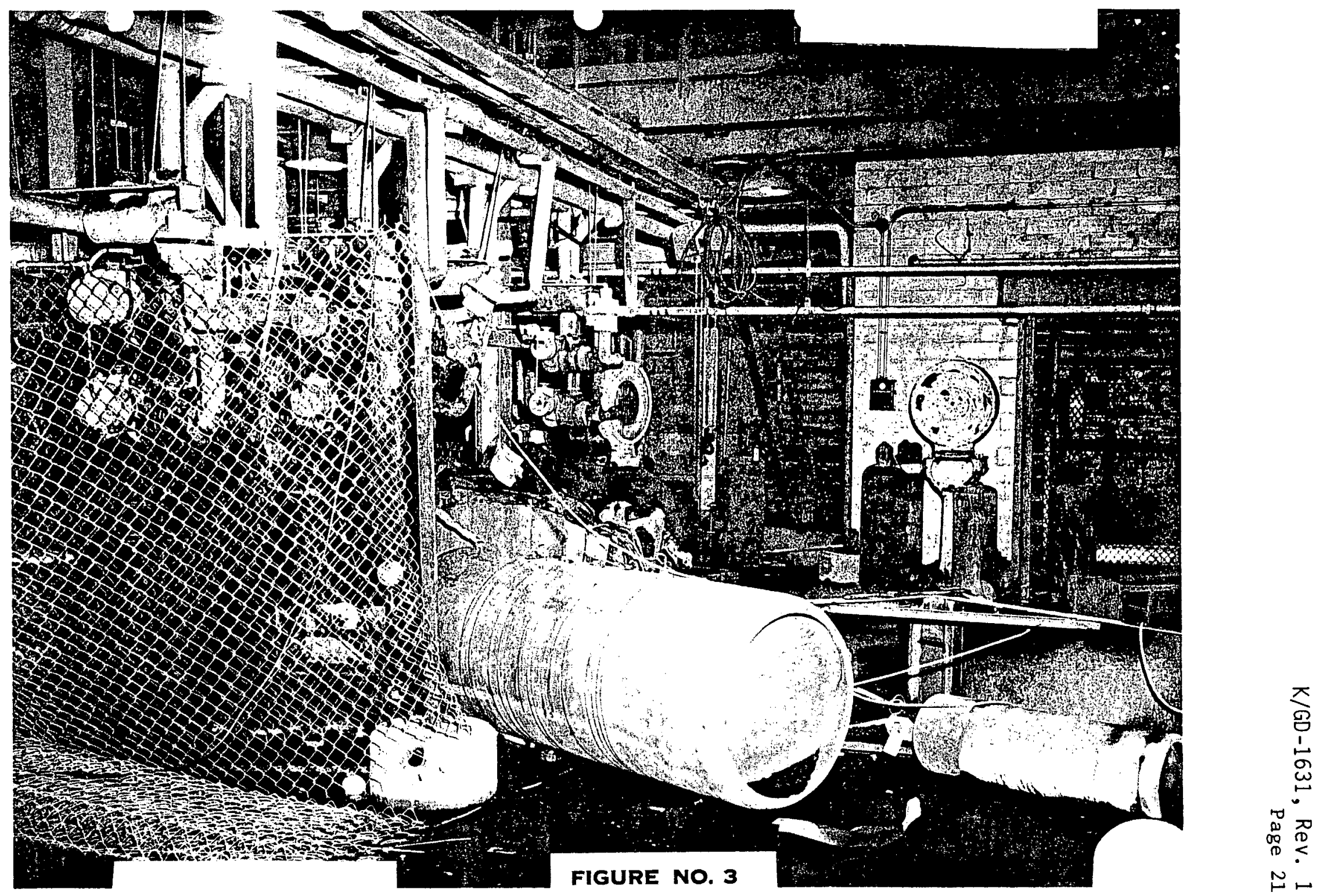






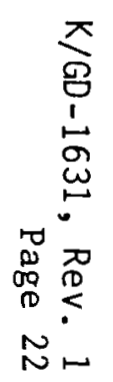




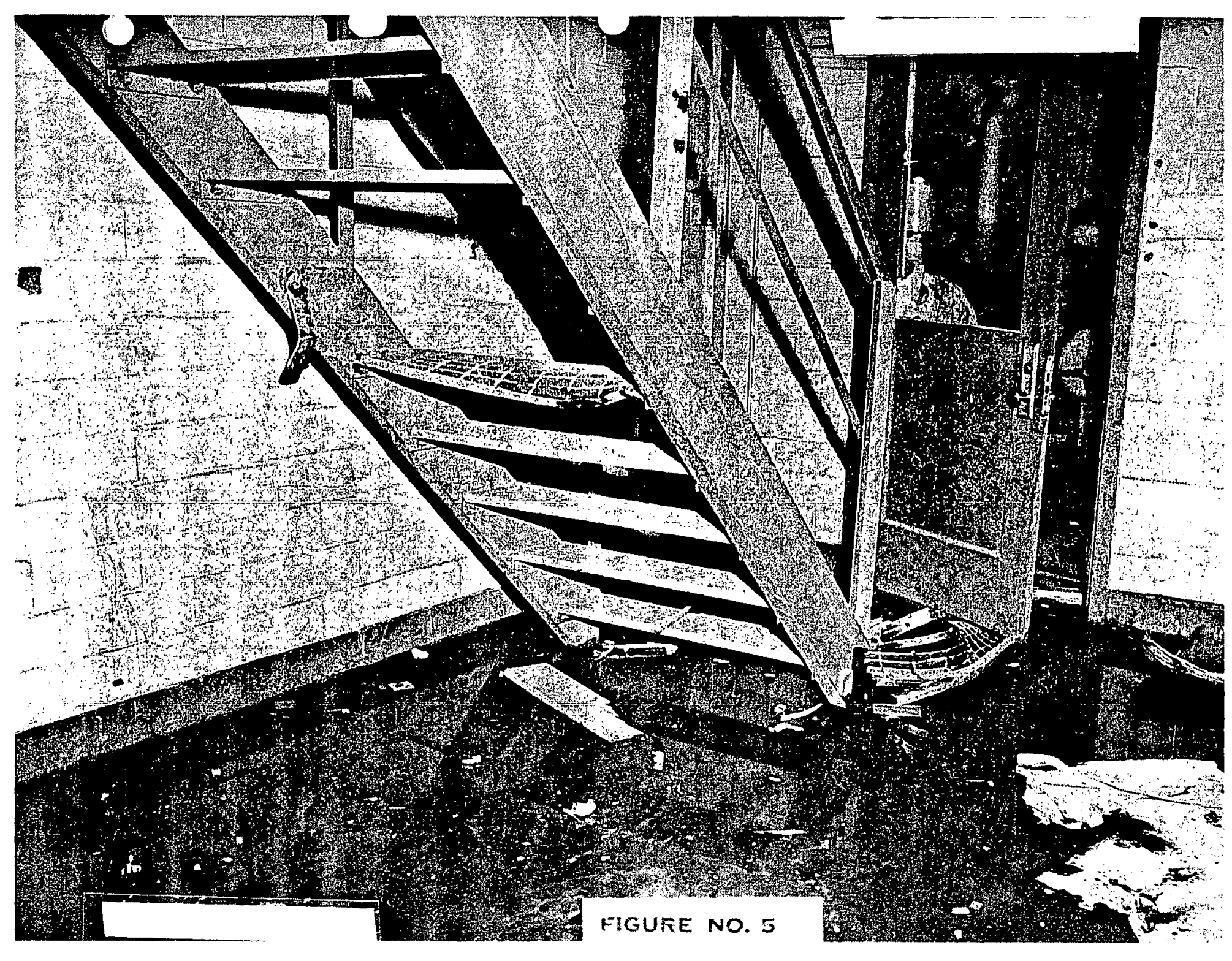

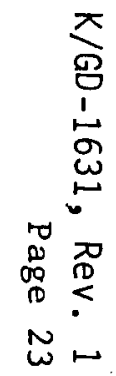




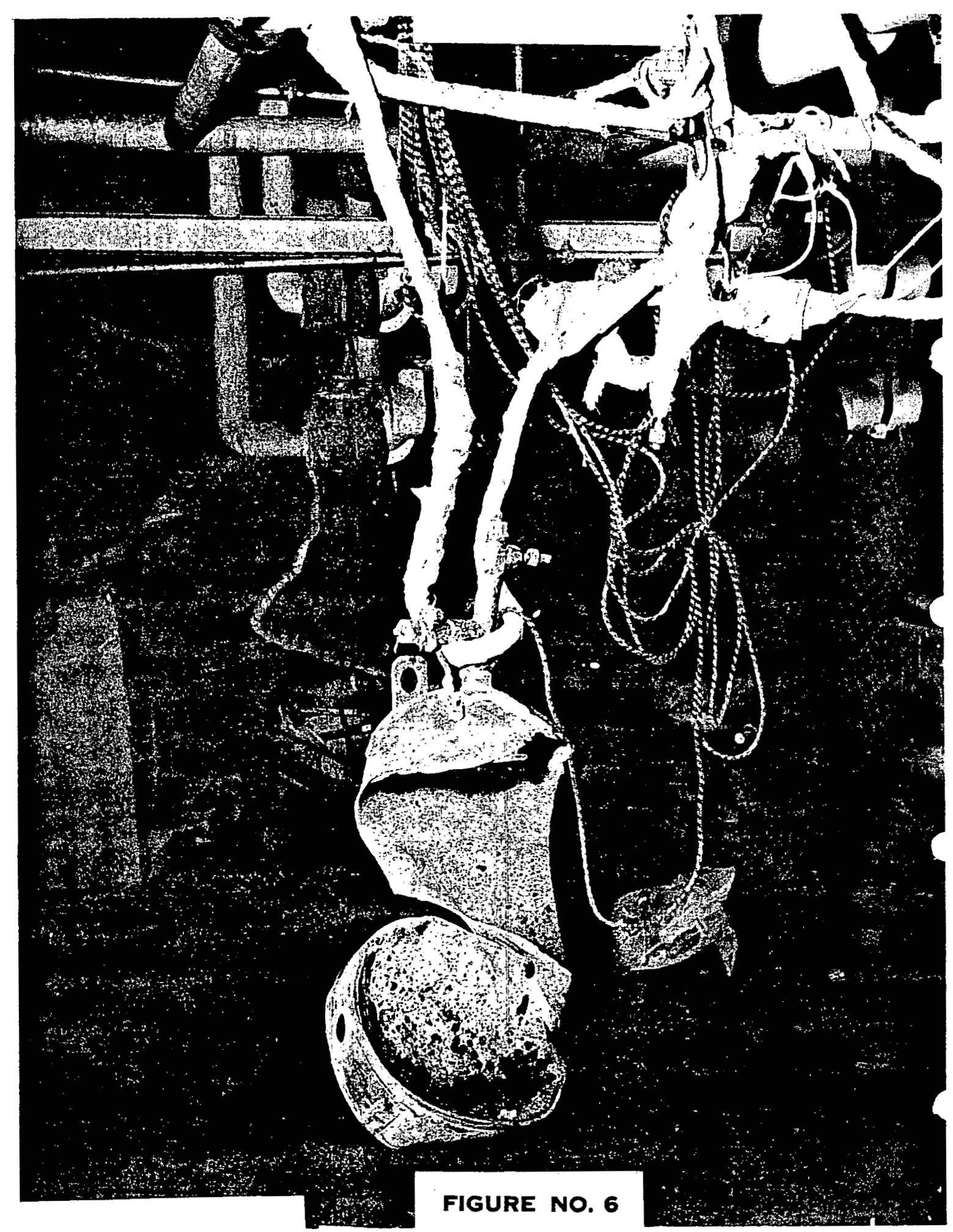




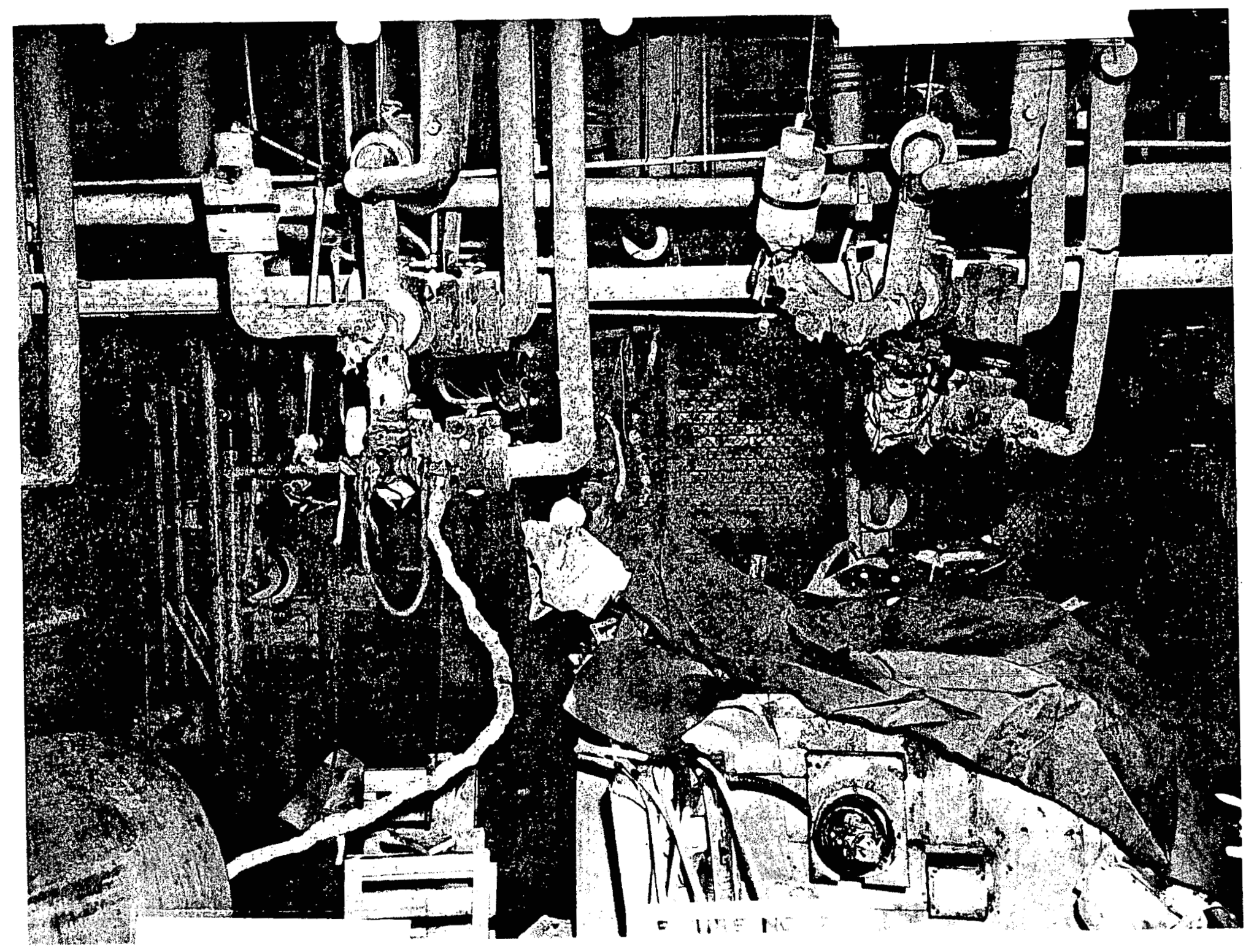

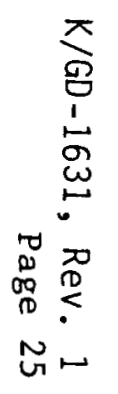


K/GD-1631, Rev. 1

Page 26

Appendix C 


\section{INTER-COMPANY CORTEQPONDENCE}

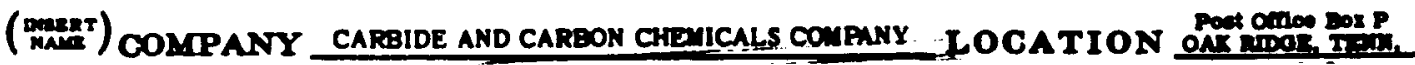

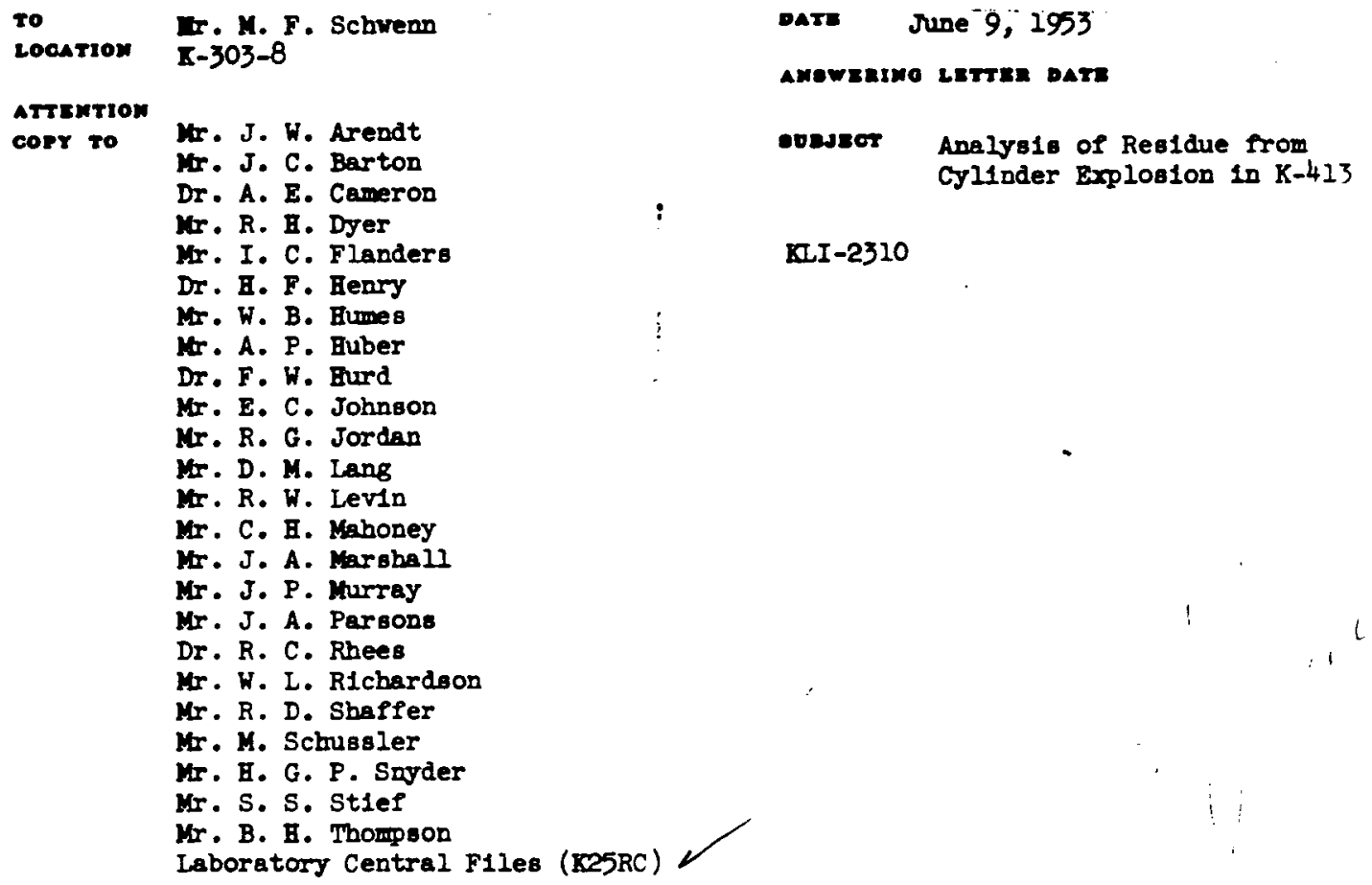

The grey powder formed by the explosion of a cyllnder contalning uranium hexafluoride in $\mathrm{K}-413$ bs been anslyzed with the hope of securing Information concerning the cause of the explosion. The following results vere obtained:

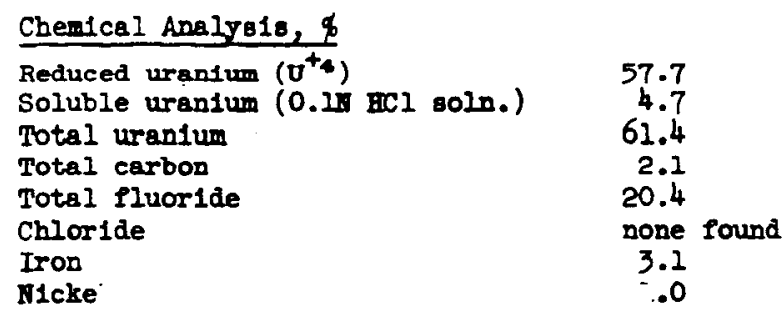




\section{Spectrographic Analyais, \$}

$\begin{array}{ll}\text { Al } & 0.1 \\ \mathrm{Cr} & 0.5 \\ \mathrm{Cu} & 0.1 \\ \mathrm{Fe} & 5 . \\ \mathrm{Mg} & 0.2 \\ \mathrm{Mn} & 0.1 \\ \mathrm{~S} 1 & 1 . \\ \mathrm{U} & \text { Strong }\end{array}$

$X$-ray analysis showed the sample to te fririctpally $\mathrm{WF}_{4}$.

The history of the cylinder and the nature of the expiosion indicate that the reaction between $U_{\mathrm{F}}$ and the reducing ageat is vegligible at ordinary storage temperatures $\left(25-35^{\circ}\right.$ C.), yet becomes visient at temperatures attainable in a vater bath. Experiments performed by A. V. Falcen and K. E. Rapp showed that the reaction between urantum kexaflusride and hydrocarbon 011 becomes vigorous at $70-90^{\circ} \mathrm{C}$, , forming $\mathrm{LF}_{\star}$, carbja, and low molecular velght fluorinsted carbon compounds (FF, $\left.F_{z} F e, C_{F} F_{0}, C_{4} F_{10}\right)$.

The findings of the latoratory strongly indicate tibat tit cylinder which exploded contalned hydrocarbon cll as weil as UFe.

We underatand that precautions are being taken to greatiy desrease the pessiblitty of getting pump oll lato cylinders wisk contaln uranium hexefluoride.

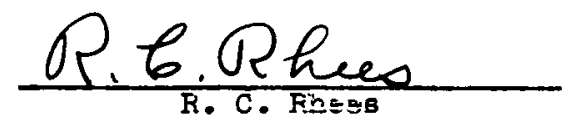

RCR : ae

Sperial Aralyols Laboratory Works Laboratory Department

Laboratcry Division 
K/GD-1631, Rev. 1

Page 29

Appendix D 


$$
K s-478
$$

CAREIDE AND CARBON CHEMICALS COMPANY

UEC

post OFfice boX $P$

OAK RIOGK. TENNESSEE

March 18, 1955

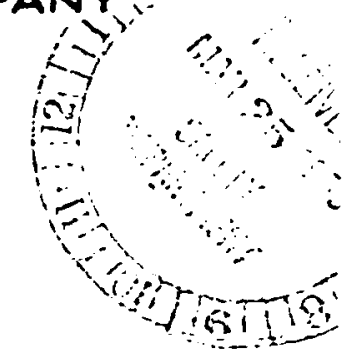

United States Atomic Energr Comission

Post Office Box E

Oak Ridge, Termessee

Attention: Mr. Ray C. Armotrong, Director, Production D1vio1on

Gentlemen:

Report of Explosion at K-25

The attached report of the formal investigation of an explosion occurring while a cylinder was being heated to feed 1 ts contents to the K-25 cascade has been prepared in accordance with Bulletin OR-SFP-5 (Serial No. 88). The Investigating compltee was composed of H. G. P. Snyder, J. A. Parsons, and L. L. Anthony of the Production Division, E. C. Johnson of the Technical Division, and H. F. Henry of the Safety and Protection Division. Action is being taken upon the reccmmendations of the committee which appears to encompass the major practicable steps for the prevention of a similar incident in the future.

Very truly yours,

CARBIDE AND CARBON CHEMICAIS COMPANY

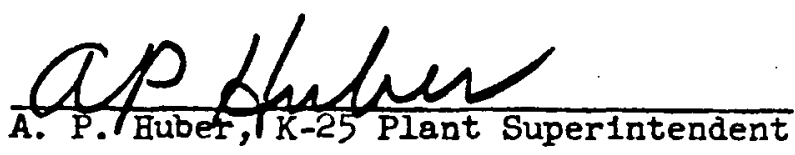

$\mathrm{HFH}: \mathrm{mb}: \mathrm{ved}$

Attachment

cc: Mr. C. E. Center

Mr. L. B. Emlet

Mr. W. L. Richardaon

Nr. M. F. Schwenn

Safety Department - K25RC 


$$
\begin{array}{r}
\text { K/GD-1631, Rev. } 1 \\
\text { Page } 31
\end{array}
$$

\author{
INVESTIGATING COMMTTTEE REPORT
}

OF AN EXPLOSION AT K-25

\begin{abstract}
KS- 478
Descripticn of Daraged Property: One feed furnace, demolished.

Minor damage to another feed furnace.

Two platform scales heavily danaged.

One 12" I.D. $x$ 4O" feed cylinder destroyed. Miscellaneous damage to lighting system.
\end{abstract}

Exteriv of Damage to Government Property: $\$ 5800$

Mnourt of Material Released: *

Vaiue ci Materials Lost: *

Time of Ircident:

Losation of Incident:

\title{
Description of Incident:
}

Wrile a partially emptied cylinder from which $\mathrm{UF}_{6}$ had been fed to the cascade was cooling down, it violently exploded without waming, severely damaging nearby equipment and releasing its contents to the atmosphere. Mthougin there were 5 employees in the room at the time of the explosion, rone vere injured in any way, either by flying debris or by the UF 6 released. A previous release of material from a similar cylinder in another furnace had occurred at 4:03 P.M. of the same day in the same room when a connection sudderily ruptured during the normal feeding cycle.

\section{Findings:}

1. Both the cylinder which exploded and the one from which a material $r$ rease had occurred earlier had been placed in the vaporization iurnaces earlier in the day, and, after normal handling, were valved into the cascade for feeding to the cascade at about 2:00 $P$. M. during the afternoon.

2. As a result of the material release which occursed at 4:03 P.M. and which was quickly brought under control by the use of dry ice, it was decided to turn of $f$ the furnaces, allow the second cylinder to cool down, and then to remove it from the feed bath; however,

* These figures apply both to this particular release and a previous release described in the report. 
t:-i cylinder comection to the cascade was left open while it was cooling. Thus, when this cylinder exploded, it had been cooling and venting for over 5 howr.

3. At the time of the explosion, the bullding operator was in the feed room along with 4 other employees who were cleaning up the area contaminated by the earller release. No one recalls any susplcious clrcumstance which would have led him to belleve the feed operation was abnormal in any way prior to the explosion.

4. None of the employees were atruck by debris, and, despite the heavy yellowloh "fog" which almost imediately filled the room, all quickly left the room.

5. The violence of the explosion is 1ndicated by the photographs attached. No. 1 shows the feed bath shortly after the explosion where a almilar undamaged one may be noted at the olde of the photograph. No. ? Bhow日 the remalns of the cylinder compared to a simtlar undamaged one.

6. Pertinent items in the history of the cylinder are as follows:

a. Both this cylinder and the one from which the earlier material release had occurred were units of a group of 33 aimilar cylinders from the $\mathrm{K}-1401$ Barrier Pllot plant, one of which had exploded on May 25, 1953, after 10 had been ouccessfully emptied. (See KS-379, attached to \& letter from Mr. A. P. Huber to Mr. R. C. Armstrong dated June 24, 1953.)

b. Since the previous incldent, all of these cylinders had been stored pending a final decision on the disposition of the Broup.

c. As a result of a decision to reduce the inventory of stored UF6 (approximately 300 cylindera) in the plant, the 2 cylindera concerned were inadvertently included in the group which was oelected for emptying.

d. Although adequate records of cylinder hlatory were maintained, these records were not traced beyond the past year, and the algnificance of this palr of cylinders escaped detection.

e. The potential hazards inberent in handing cylinders of this group were not 1dentified except by the SF transfer record noted above.

7. Since it has been suspected that the previous explosion of May 25, 1953, was the result of hydrocarbon oll being mixed with the UF6, experiments had been Initiated to indicate the explosivity of such mixtures, and these had indicated that they would explode at temperatures in the range of $70^{\circ}-90^{\circ} \mathrm{C}$. At the time of this explosion, It is estimated that at least oome of the contents of the cylinder were probably well within this range. 
8. As a result of the previous incldent, the followlng steps had been taker in accord with the recommendations of the lnvestigating comittee and their later modiflcations:

a. Standard Reference Information had been prepared and distributed on practically all of the potentially hazardous chemicals at $\mathrm{K}-25$.

b. A barricaded facility had been provided for UF 6 tranafer operations; bowever, the comittee doubts if the present facility would have withstood an explosion as violent as the one involved in this instance.

c. A review of vacuum pumps used in UF6 transfer systems was made and, where practlcable, fluorocarbon ofl was spec1fled for use in those not already uaing 1 .

d. The cylinders 1mmediately concerned in the original explosion were removed to a separate storage location; however, as lnd1cated above, they were not 80 marked that imediate 1dent1pication of thelr hazarda would be possible.

Conclusions:

Although the results of the explosion made positive 1dentification of 1ta cause difficult, it was the rather definite opinion of the committee that it did reault from hydrocarbon oll baving gotten into the cylinder of UF 6 during 1ta usage in the K-1401 Barrier P1lot plant.

Recommendations:

In addition to continued follow-up on the recomendations made at the time of the previous incident, the lavestigating comittee suggeste that:

1. A more positive method for immediate 1dentification of conta1ner contenta with specific attention given to potent1ally hazardous materisis be developed and employed.

2. Pending a laboratory investigation to develop a method of sefely disposing of cylinders from the involved facility, the subject cylinders should be segregated and individually ldentified until the ultimate method of disposal can be formulated.

3. It is recomended that a review be made of the adequacy of the existing sampling pacility to determine whether the present barr1cades can be atrengthened to provide adequate personnel protection in the event of an incident similar to this one.

4. Adaftional experimental 1nvestigation of the explosive properties of materials fed to the $\mathrm{K}-25$ cascade be made where the adviability of such action is indicated.

R. F. Henry :mh :ved

3-18-55 
K/GD-1631, Rev. 1

Page 34

Appendix E 


\author{
INTER-GOMPANY CORRESPONDENCE

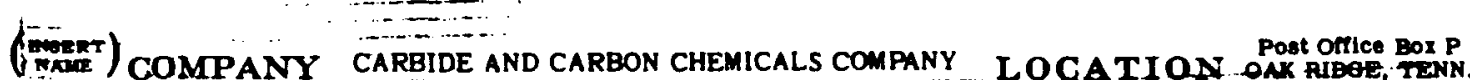 \\ To \\ LOCATION \\ Mr. M. F. Bchwenn \\ $\mathrm{K}-303-8$ \\ ATTENTION \\ COPY TO \\ Mr. A. P. Huber \\ Production \& Chemicals Divisions \\ Date April 6, 1955 \\ ANBWERING LETTER DATE \\ -osject Analysis of Residue from \\ Cyl1nder Bxplosion in K-33
} Central File

Kr. R. H. Dyer

Mr. J. A. Marshall

Mr. J. A. Parsons

Vir. R. D. Bhaffer

Wr. H. G. P. Snyder

Mr. E. O. Bternberg

Mr. S. S. Stief

Mr. B. H. Thomson

Safety and Protection Division

Central File

Dr. B. F. Henry

Mr. W. L. Rlchardson

Technical Divis1on, K-1005 File

MIBB M. E. Adams (K25RC)

Mr. J. C. Barton

Mr. I. C. Flonders

Mr. E. C. Johnson

Mr. T. Krasnosk1

Mr. D. M. Lang

Mr. C. B. Mahoney

Mr. J. T. Mottern

Dr. R. C. Rhees

Mr. M. Schussler
KLI-345I

Uraniu Control Department Central F1le

Mr. J.W. Arendt

Four samples of material collected from the $\mathrm{K}-33$ vaporization room after the March 10th explosion of a cylinder contalning urantur hexafluorlde have been analyzed in an attempt to determine the cause of the explosion. Three different types of material vere collected. The first was a finely divided, grey porder removed from equipment adjacent to the point of explosion; the second was lumps of green and black material taken from the floor in the erea of maximum damage; the third vas a resinous, black residue adhering to the manifold housing after the 1008 porder had been removed. The fourth saple recelved vas a porder rewoved from the body of the valve frai the ruptured cjlinder. Thls material had the same appearance as the grey porder nentioned above. The folloring analytical results were obtalned: 


$$
\begin{array}{r}
\mathrm{K} / \mathrm{GD}-1631 \text {, Rev. } 1 \\
\text { Page } 36
\end{array}
$$

KII -3451

CHEMTCAL amaLYses (\$)

Grey Powder Lump Material $\begin{gathered}\text { Black } \\ \text { Resinous }\end{gathered}$ Material* $\begin{aligned} & \text { Material } \\ & \text { Prom Body } \\ & \text { of Valve }\end{aligned}$

Total uranium

Reduced uranium $\left(\mathrm{U}^{+4}\right)$

Total fluoride

Total carbon

Iron

Welght 1088 on 1galtion
65.8

45.3

22.0

2.85

1.98
70.1

48.0

24.7

2.46

-...-

-..-
---

$-\cdots$

- -

-

$-\cdots$

31.3
-..-

-.-

1.86

1.86

-..-

* This material 1gnited and sustained a plawe when heated. The residue after 1gatition vas impure uranium oxides.

\section{SPBCTROCHEYTCAL ANALYGES (PPM)**}

\begin{tabular}{|c|c|c|}
\hline Al & 300 & 80 \\
\hline B & 20 & - \\
\hline $\mathrm{Cr}$ & 40 & \\
\hline Cu & 100 & \\
\hline $\mathrm{Fe}$ & 20000 & 1 \\
\hline$M_{B}$ & 2000 & \\
\hline Mn & 40 & \\
\hline Ma & 2000 & \\
\hline S1 & 100 & \\
\hline $2 n$ & 2000 & \\
\hline
\end{tabular}

Grey Powder Lump Material

* Spectrochemical analysis was made only on the first two samples above.

The grey powder produced by this explosion 18 olmlar in appearance and analysis to that produced by the explosion of a cylinder in $\mathrm{K}-413$ two years ago (KII-2310). All samples analyzed indicate the urantum hexafluoride in the exploding cylinder vas in contact with an organic aubstance, probably hydrocarbon ofl, which resulted in violent reducing action on the uranium bexafluoride wen the cylinder was heated.
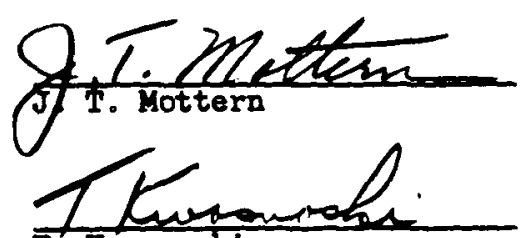

T. Krasnosk1

Special Analysis Department

$/ \mathrm{ja}$

Tachnical. Dtrision 
K/GD-1631, Rev. 1

Page 37

DISTRIBUTION OF K/GD-1631, Rev. 1

Department of Energy - Oak Ridge Operations

R. H. Dyer

M. Theisen (3)

Department of Energy

Office of Scientific and Technical Information (2)

Kerr-McGee Corporation

J. Kauffman (3)

Martin Marietta Energy Systems, Inc. - ORGDP

E. J. Barber

J. T. Bradbury (3)

Enrichment Technology Library (5)

ORGDP Records Department - RC

A. S. Quist 